\title{
Suppurative intracranial processes in 15 domestic ruminants ${ }^{1}$
}

\author{
Antônio Carlos Lopes Câmara ${ }^{2 *}$, André Menezes do Vale², Jael Soares Batista ${ }^{3}$, \\ Francisco Marlon C. Feijó ${ }^{3}$ and Benito Soto-Blanco ${ }^{4}$
}

\begin{abstract}
Câmara A.C.L., Vale A.M., Batista J.S., Feijó F.M.C. \& Soto-Blanco B. 2014. Suppurative intracranial processes in $\mathbf{1 5}$ domestic ruminants. Pesquisa Veterinária Brasileira 34(5):421-426. Hospital Veterinário, Universidade Federal Rural do Semi-Árido, Avenida Francisco Mota 572, BR-110 Km 47, Presidente Costa e Silva, Mossoró, RN 59625-900, Brazil. E-mail: aclcamara@yahoo.com.br

In addition to listeriosis which is relatively common in ruminants, there are three other uncommon suppurative intracranial processes (SIP) identifiable in adult ungulates as brain abscess, basilar empyema and suppurative meningitis. The present paper reports the epidemiological, clinical, laboratorial, pathological and microbiological findings of 15 domestic ruminants with SIP. A total of 15 animals were selected (eight sheep, four cattle and three goats); with the definitive diagnoses of basilar empyema $(n=3)$, brain abscess $(n=1)$, listeriosis $(n=5)$ and suppurative meningitis $(n=6)$. Hematology revealed leukocytosis with inversion of the lymphocyte/ neutrophil ratio in 4 cases. In the majority of animals, cerebrospinal fluid (CSF) presented light yellow coloration and cloudy aspect due to neutrophilic pleocytosis (15 - 997 leukocytes $/ \mu \mathrm{L}$ ). Microbiological culture of CSF or central nervous system (CNS) fragments resulted on isolation of Trueperella (Arcanobacterium) pyogenes, Listeria monocytogenes, Escherichia coli and Stenotrophomonas sp. In a goat with thalamic abscess, microbiological assay was not performed, but Gram positive bacilli type bacteria were observed in histology. The diagnosis of these outbreaks was based on the association of epidemiological, clinical, pathological and bacteriological findings; reiterating that the infectious component remains an important cause of CNS disease in domestic ruminants and also shows the need for dissemination of information about the most effective preventive measures for the ranchers.
\end{abstract}

INDEX TERMS: Basilar empyema, brain abscess, listeriosis, suppurative meningitis, livestock.

RESUMO.- [Processos supurativos intracranianos em 15 ruminantes domésticos.] Além da listeriose, que é relativamente comum em ruminantes, existem outros três processos supurativos intracranianos (PSI) identificáveis em ungulados adultos, que não são comuns, como: abscesso cerebral, empiema basilar e meningite supurativa. 0 presente trabalho tem como objetivo relatar os achados epidemiológicos, clínicos, laboratoriais, patológicos

\footnotetext{
${ }^{1}$ Received on March 21, 2014.

Accepted for publication on May 6, 2014.

${ }^{2}$ Hospital Veterinário, Universidade Federal Rural do Semi-Árido (UFERSA), Av. Francisco Mota 572, BR-110 Km 47, Mossoró, RN 59625900, Brazil. *Corresponding author: aclcamara@yahoo.com.br

${ }^{3}$ Docente do Curso de Medicina Veterinária, Departamento de Ciências Animais, UFERSA, Mossoró, RN.

${ }^{4}$ Departamento de Clínica e Cirurgia Veterinárias, Escola de Veterinária, Universidade Federal de Minas Gerais (UFMG), Av. Pres. Antônio Carlos 6627, Belo Horizonte, MG 31270-901, Brazil.
}

e microbiológicos de 15 ruminantes domésticos com PSI. 0 total de 15 animais foi selecionado (oito ovinos, quatro bovinos e três caprinos), com o diagnóstico definitivo de empiema basilar $(\mathrm{n}=3)$, abscesso cerebral $(\mathrm{n}=1)$, listeriose $(n=5)$ e meningite supurativa $(n=6)$. A hematologia revelou leucocitose com inversão da relação linfócito/ neutrófilo em quatro animais. Na maioria dos animais, a análise do líquido cefalorraquidiano (LCR) revelou coloração amarelado clara e aspecto turvo devido à pleocitose neutrofílica (15 - 997 leucócitos/ $\mu \mathrm{L}$ ). A cultura microbiológica de LCR ou de fragmentos do sistema nervoso central (SNC), permitiu o isolamento de Trueperella (Arcanobacterium) pyogenes, Listeria monocytogenes, Escherichia coli e Stenotrophomonas sp. No caprino com abscesso de tálamo, a cultura microbiológica não foi realizada, mas bactérias Gram positivas tipo bacilos foram observadas na histologia. 0 diagnóstico desses surtos foi baseado na associação dos achados epidemiológicos, clínicos, patológicos e bac- 
teriológicos; reiterando que o componente infeccioso continua sendo uma causa importante de doença do SNC em ruminantes domésticos e também mostra a necessidade de disseminação da informação sobre as medidas preventivas mais eficazes para os criadores.

TERMOS DE INDEXAÇÃO: Abscesso cerebral, animais de produção, empiema basilar, listeriose, meningite supurativa.

\section{INTRODUCTION}

In addition to listeriosis which is relatively common in ruminants, there are three additional suppurative intracranial processes (SIP) identifiable in adult ungulates that are not common. Considering all species, probably they occur in the following order of frequency: brain abscess, basilar empyema (pituitary abscess) and suppurative meningitis (Mayhew 2009). Direct extension of necrosuppurative processes involving other structures of the skull such as head trauma, dehorning lesions and otitis media/interna occasionally result in secondary piogranulomatous intracranial lesions. Considering this, cerebrospinal fluid (CSF) analysis presents as an important component of the diagnostic evaluation of ruminants presenting with clinical signs localizing to the central nervous system (CNS). Laboratory evaluation of CSF is the most direct antemortem method of characterizing a CNS disease process and can provide a definitive disease diagnosis, direct further diagnostic testing, or help guide appropriate treatment (Stokol et al. 2009). Due to the lack of informations on SIP in ruminants in the national literature, the present work aims to report the epidemiological, clinical, laboratorial, pathological and microbiological findings of 15 domestic ruminants with SIP.

\section{MATERIALS AND METHODS}

A survey in the files of the ruminants attended at the Veterinary Hospital of the Federal Rural University of the Semi-arid (HOVET-UFERSA), Mossoró, RN, Northeastern Brazil, was conducted to identify the diagnostic reports of SIP. Three cases of basilar empyema attended by one of the authors (ACLC) in Brasília, Distrito
Federal, Mid-Western Brazil, were also included. A total of 15 animals were selected (eight sheep, four bovines and three goats); with the definitive diagnose of basilar empyema $(n=3)$, brain abscess $(n=1)$, listeriosis $(n=5)$ and suppurative meningitis $(n=6)$. Each diagnostic report was retrieved and reviewed; including epidemiological, clinical, laboratorial, pathological and microbiological findings.

The ruminants were clinically examined according to Dirksen et al. (1993) and neurological examination followed the recommendations of Mayhew (2009). Blood samples were collected through jugular venipuncture in vacuum tubes with EDTA anticoagulant (10\%) for the complete blood count and determination of total plasma protein (Jain 1993). Samples of CSF were collected through cerebellar-medullary cisterns and analyzed according to previously described methodology (Scott 2004, 2010). All ruminants that died during hospitalization were necropsied. Tissue fragments were collected from the lungs, liver, kidneys, heart, gastrointestinal tract and CNS, which were fixed in buffered formalin $10 \%$, embedded in paraffin, sliced to a thickness of $5 \mu \mathrm{m}$ and stained with hematoxylin and eosin (HE). Aliquots of CSF and/or CNS fragments were collected aseptically and submitted for microbiological assays (MacFaddin 2000).

\section{RESULTS}

Epidemiological and clinical data, hematological findings and CSF analysis are presented in Tables 1, 2 and 3, respectively.

\section{Basilar empyema (pituitary abscess syndrome)}

Three 8 to 11-month-old calves from two farms were evaluated. The disease was associated in two calves with necrotizing rhinitis (Cases 2 and 3 ) due to the use of a controlled suckling device, and in the other calf (Case 1) was associated with abscedative pneumonia. Most important clinical findings were nervous signs of cerebral and brainstem origin with clinical evolution of 7-20 days. Most frequent clinical signs consisted of depression, head pressing, tongue hypotony and circling. Hematology revealed severe leucocytosis by neutrophilia in two calves (Cases 1 and 2), and in Case 3 degenerative left turn and absolute lymphope-

Table 1. Epidemiology and clinical evolution in 15 domestic ruminants with suppurative intracranial processes

\begin{tabular}{|c|c|c|c|c|c|c|c|c|}
\hline Case & Specie & Breed & Sex & Month/ Year & Age & Clinical evolution $^{\mathrm{a}}$ & Resolution & Diagnose \\
\hline 1 & Bovine & Holandesa & $\mathrm{F}$ & $08 / 2002$ & 11 months & 10 & Death & Basilar empyema \\
\hline 2 & Bovine & Crossbred & M & $05 / 2005$ & 8 months & 7 & Discharged & Basilar empyema \\
\hline 3 & Bovine & Tabapuã & M & $01 / 2005$ & 10 months & 20 & Death & Basilar empyema \\
\hline 4 & Goat & Crossbred & $\mathrm{F}$ & $11 / 2011$ & 5 years & 2 & Death & $\begin{array}{l}\text { Thalamus abscess } \\
\text { and leptomeningitis }\end{array}$ \\
\hline 5 & Sheep & Santa Inês & M & $04 / 2010$ & $\mathrm{ND}^{\mathrm{b}}$ & 10 & Death & Listeriosis \\
\hline 6 & Sheep & Crossbred & $\mathrm{F}$ & $02 / 2011$ & 18 months & 4 & Death & Listeriosis \\
\hline 7 & Sheep & Crossbred & $\mathrm{F}$ & $02 / 2011$ & 2 years & 3 & Death & Listeriosis \\
\hline 8 & Sheep & Crossbred & M & $02 / 2011$ & 6 months & 4 & Death & Listeriosis \\
\hline 9 & Sheep & Crossbred & $\mathrm{F}$ & $02 / 2011$ & 5 years & 3 & Death & Listeriosis \\
\hline 10 & Goat & Crossbred & M & $05 / 2013$ & 2 months & 3 & Death & Suppurative meningitis \\
\hline 11 & Goat & Anglo Nubian & $\mathrm{F}$ & $05 / 2013$ & 21 days & 1 & Discharged & Suppurative meningitis \\
\hline 12 & Sheep & Morada Nova & $\mathrm{F}$ & $04 / 2013$ & 4 years & 3 & Death & Suppurative meningitis \\
\hline 13 & Sheep & Morada Nova & $\mathrm{F}$ & $04 / 2013$ & 3 years & 3 & Death & Suppurative meningitis \\
\hline 14 & Bovine & Crossbred & $\mathrm{F}$ & $05 / 2010$ & 6 days & 4 & Death & Suppurative meningitis \\
\hline 15 & Sheep & Somalis & M & $10 / 2013$ & 35 days & 2 & Death & Suppurative meningitis \\
\hline
\end{tabular}

a Time between the onset of clinical signs observed by the owner until clinical examination, ${ }^{\mathrm{b}} \mathrm{ND}=$ not determined. $\mathrm{M}=$ male, $\mathrm{F}=$ female. 
Table 2. Hematology $(n=8)$ and total plasma protein $(n=7)$ in domestic ruminants with suppurative intracranial processes

\begin{tabular}{|c|c|c|c|c|c|c|c|c|c|c|}
\hline Parameter & Case 1 & Case 2 & Case 3 & Case 4 & Case 6 & Case 10 & Case 11 & Case 14 & $\begin{array}{l}\text { Reference values } \\
\text { (Sheep and Cattle) }\end{array}$ & $\begin{array}{c}\text { Reference } \\
\text { values (Goats) }\end{array}$ \\
\hline Packed cell volume (\%) & 33 & 38 & 33 & 50 & 35 & 34 & 34 & 29 & $24-50$ & $22-38$ \\
\hline $\mathrm{RBC}^{\mathrm{b}}(\mathrm{x} 106 / \mu \mathrm{L})$ & 8.2 & 9.1 & 8.1 & 23.2 & 11.3 & 9.8 & 12.3 & 6.6 & $8-16$ & 8-18 \\
\hline Hemoglobin (g/dL) & 11.3 & 11.6 & 10.4 & 16.1 & 11.2 & 10.9 & 10.9 & 9.3 & 8-16 & 8-12 \\
\hline $\begin{array}{l}\text { Mean corpuscular } \\
\text { volume (fL) }\end{array}$ & 40 & 41 & 40 & 37 & 30 & 34 & 27 & 44 & $23-48$ & $16-25$ \\
\hline Leukocytes $(/ \mu \mathrm{L})$ & 23,700 & 27,100 & 7,300 & 9,000 & 7,200 & 13,200 & 19,400 & 26,000 & $4,000-12,000$ & $4,000-13,000$ \\
\hline Neutrophils $(/ \mu \mathrm{L})$ & 15,705 & 15,989 & 3,212 & 5,850 & 5,112 & 6,468 & 10,476 & 16,120 & $400-6,000$ & $1,200-7,200$ \\
\hline Lymphocytes $(/ \mu \mathrm{L})$ & 6,873 & 2,410 & 1,825 & 2,700 & 864 & 5,808 & 7,372 & 6,760 & $1,600-9,000$ & $2,000-9,000$ \\
\hline Monocytes $(/ \mu \mathrm{L})$ & 1,185 & 3,794 & 438 & 270 & 360 & 792 & 1,358 & 780 & $0-750$ & $0-550$ \\
\hline Eosinophils $(/ \mu \mathrm{L})$ & 237 & - & - & 180 & 72 & 132 & 194 & - & $0-1,000$ & $50-650 \mathrm{~d}$ \\
\hline Bands $(/ \mu \mathrm{L})$ & - & 1,825 & 4,065 & - & - & - & - & 2,340 & 0 & 0 \\
\hline Total plasma protein (g/dL) & 9.4 & 8.6 & 7.8 & 8.8 & 6.6 & 6.4 & 7.2 & $\mathrm{ND}^{\mathrm{c}}$ & $6,0-7,9$ & $6,0-7,5$ \\
\hline
\end{tabular}

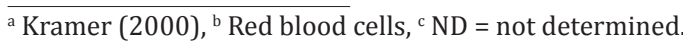

Table 3. Results of physical examination $(n=12)$, total cell count $(n=8)$ and microbiological culture $(n=8)$ from cerebrospinal fluid of domestic ruminants with suppurative intracranial processes

\begin{tabular}{|c|c|c|c|c|c|c|c|c|}
\hline $\begin{array}{l}\text { Parameter } \\
\text { Case }\end{array}$ & Aspect & Color & Fibrin clot & Density & $\begin{array}{l}\text { Total protein } \\
\text { (mg/dL) }\end{array}$ & $\mathrm{RBC}^{\mathrm{a}}(/ \mu \mathrm{L})$ & $\begin{array}{c}\text { Leukocytes } \\
(/ \mu \mathrm{L})\end{array}$ & $\begin{array}{l}\text { Microbiological } \\
\text { culture }\end{array}$ \\
\hline 1 & Cloudy & Reddish & Present & 1.014 & 500 & 72,000 & 50 & $\begin{array}{c}\text { T. }\left(\begin{array}{c}\text { Arcanobacterium }) \\
\text { pyogenes }\end{array}\right.\end{array}$ \\
\hline 2 & Clear & Colorless & Absent & 1.006 & 363 & 0 & 15 & $\mathrm{ND}^{\mathrm{b}}$ \\
\hline 3 & Clear & Colorless & Absent & 1.008 & 412 & 11 & 17 & ND \\
\hline 4 & Cloudy & Light yellow & Present & 1.010 & 300 & 235 & 997 & ND* \\
\hline 5 & Cloudy & Yellow & Present & 1.008 & 360 & 95 & 66 & L. monocytogenes \\
\hline 6 & Cloudy & Light yellow & Present & 1.005 & 300 & 176 & 92 & L. monocytogenes \\
\hline 7 & Cloudy & Light yellow & ND & ND & ND & ND & ND & L. monocytogenes \\
\hline 8 & Cloudy & Light yellow & ND & ND & ND & ND & ND & L. monocytogenes \\
\hline 9 & Cloudy & Light yellow & ND & ND & ND & ND & ND & L. monocytogenes \\
\hline 10 & Cloudy & Light yellow & Present & 1.030 & 300 & 2,150 & 598 & E. coli \\
\hline 14 & Purulent & Yellow green & ND & ND & ND & ND & ND & Stenotrophomonas sp. \\
\hline 15 & Cloudy & Light yellow & Present & 1.020 & ND & 58 & 493 & ND \\
\hline $\begin{array}{l}\text { Reference } \\
\text { values }^{c}\end{array}$ & Clear & Colorless & Absent & $<1.010$ & $<400$ & Few & $<10$ & None \\
\hline
\end{tabular}

nia. CSF analysis showed light neutrophilic pleocytosis (1550 leukocytes $/ \mu \mathrm{L}$ ). Trueperella (Arcanobacterium) pyogenes was isolated from CSF of Case 1 . Mortality rate achieved $66.6 \%$, since Case 2 recovered after antibiotic treatment. Necropsy findings included single para-hypophyseal abscesses or located in the glandular parenchyma; one calf showed necrotizing rhinitis and another abscedative pneumonia. Histological exams of the CNS revealed complete absence of normal pituitary tissue due to the wide necrosis and neutrophilic inflammatory infiltrate. This lesion pattern was also observed in the lungs of Case 1 . These three cases of basilar empyema were reported by Câmara et al. (2009).

\section{Brain abscess}

One 5-year-old doe (Case 4) was presented with history of nervous signs in the past two days. Clinical signs included apathy, fever $\left(40.2^{\circ} \mathrm{C}\right)$, mydriasis, dehydration, tongue hipotony, convulsion episodes with vocalization, and inability to stand. Clinical evolution was two days, and the doe died 18 hours after initial treatment. This animal was first presented approximately one month earlier with the complaint of caseous lymphadenitis in the parotideal lymphnode and treated for this disease. Hematology revealed inversion of the lymphocyte/ neutrophil ratio and CSF analysis showed turbid aspect, yellowish coloration and high neutrophilic pleocytosis (997 leukocytes/ $\mu \mathrm{L}$ ). Necropsy findings were limited to the CNS and consisted of a $3 \mathrm{~cm}$ abscess located in the right telencephalic hemisphere, more precisely on the thalamus, pressuring the adjacent structures. Microscopic findings consisted of neutrophilic aggregates and cellular debris involved by mononuclear cells and connective tissue proliferation. Multifocal areas of necrosis accompanied by neutrophilic inflammatory cells infiltration multifocal were also observed. Others findings consisted of fibrinopurulent leptomeningitis characterized by edema, fibrin clots and intense neutrophilic infiltrate. In this case, microbiological assay was not performed but Gram positive bacilli type bacteria were observed in the histology.

\section{Listeriosis}

One sporadic case in a ram from a ranch located in Limoeiro do Norte, Ceará (Case 5); and an outbreak of listerioris in a sheep flock in Governador Dix-Sept Rosado, Rio Grande do Norte (Cases 6-9), were diagnosed. In the outbreak, the rancher stated the offering of silage during the dry season for the flock composed of about 600 sheep. Approximately one month after, four sheep died in the farm after clinical evolution of four days. Another four sheep were 
transported to the HOVET-UFERSA but just one ewe arrived alive and was clinically evaluated. Clinical signs were apathy, fever $\left(40^{\circ} \mathrm{C}\right)$, bilateral blindness with mydriases, tongue hypotony, dirty nostrils, nystagmus, and right circling with sporadic falls. The ewe died $24 \mathrm{~h}$ after treatment was initiated. Hematology revealed inversion of the neutrophil/ lymphocyte ratio. CSF analysis showed turbid aspect, yellow (Case 5) to light yellow (Case 6) coloration and neutrophilic pleocytosis with 66 (Case 5) and 92 (Case 6) leukocytes/ $\mu \mathrm{L}$. Listeria monocytogenes was isolated from CSF or CNS samples (Cases 5-9) submitted to microbiological assays. All five sheep necropsied presented as gross lesions meningeal congestion and clouding of CSF. Histopathologically, the main feature was meningoencephalitis of the medulla oblongata, pons and mesencephalon; with multifocal microabscesses, focal meningitis and gliosis.

\section{Suppurative meningitis}

An outbreak of suppurate meningitis occurred in a small ruminant farm feed with poor quality roughage (Echinochloa pyramidalis). Two adult sheep (Cases 12 and 13) died after clinical evolution of three days and two kids (2-month-old, Case 10; 21-day old, Case 11) were clinically examined and treated properly. Clinical examination revealed lateral recumbency, vocalization, opisthotonos, neck stiffness, bilateral corneal opacity, fever $\left(41.3^{\circ} \mathrm{C}\right)$, tachycardia, dehydration and paddling. Hematology revealed light (Case 10) and high (Case 11) leukocytosis with neutrophilia in the latter. However CSF analysis showed a turbid aspect, light yellow coloration and pleocytosis (598 leukocytes/ $\mu \mathrm{L}$ ) with predominance of polymorphonuclear cells and bacteria. The older kid died about two hours after the clinical examination; the 21-day-old kid responded to treatment and fully recovered. Necropsy findings consisted of hyperemia, opacity and presence of fibrinopurulent exudate in the meninges, the cerebral cortex sulci and brain stem. Microscopically, there was a mixed inflammatory infiltrate involving the meninges of the parietal and temporal cortexes and brainstem. Edema and neuronal degeneration was also noted. Microbiological culture of a CSF aliquot and brain tissue of one kid (Case 10) allowed the isolation of Escherichia coli. On another farm located in Tauá-CE, the disease occurred in a 35-day-old lamb of the Somalis breed (Case $15)$, and this was the only case in the property with others 148 sheep in different ages. CSF analysis and pathological findings were similar to those on the E. coli outbreak, but in this case no microbiological culture was performed.

A six-day-old female calf (Case 14) was presented for examination after a four-day evolution of nervous signs. The owner stated that the calf promptly ingested the colostrum. Clinical exam revealed hyperthermia $\left(39.7^{\circ} \mathrm{C}\right)$, anorexia, ophtalmitis, dehydration, opisthotonos and facial, trigeminal, hypoglossal and abducent cranial nerve impairment. Hematology presented leukocytosis (26,000 leukocytes $/ \mu \mathrm{L})$ with neutrophilia $(16,120 / \mu \mathrm{L})$ and regenerative left turn $(2,340$ bands $/ \mu \mathrm{L})$. CSF analysis demonstrated purulent secretion; that was send for microbiological assay and revealed Stenotrophomonas sp. The calf died within 24 hours and macroscopic findings consisted of ophtalmitis and purulent discharge in the navel with thickening of the umbilical veins. CNS presented congestion, opacity, purulent exudate in the meninges, flattening of the cerebral gyri and cerebellar herniation. Stenotrophomonas sp was also isolated from meningeal samples. Histopathological examination was not performed.

\section{DISCUSSION}

Basilar empyema is a neurological disease that presents sporadically or in outbreaks affecting mainly calves (Loretti et al. 2003); and several degrees of cranial nerves involvement are observed (Fernandes \& Schild 2007). In the present study three sporadic cases occurred in two properties with no history of the disease. Nervous signs were correlated to the pressure of the abscesses in the surrounding structures, causing evident uni or bilateral cranial nerves paralysis or hemiplegia, especially of the abducent, trigeminal and oculomotor nerves. Microbiological culture identified T. (Arcanobacterium) pyogenes, the most common bacteria in chronic suppurative lesions of the brain in cattle (Fernandes et al. 2000, Mayhew 2009). The finding of necrotizing rhinitis (Cases 2 and 3) strongly suggests that such cases are secondary to traumatic rhinitis as in previous reports of the disease in Rio Grande do Sul (Fernandes et al. 2000, Loretti et al. 2003). The evidence of abscedative pneumonia (Case 1) allows the possibility of such disease had been the primary site of infection, since pyogenic agents might achieve the carotidal rete mirabile by haematogenous or lymphatic vessels from primary inflammatory processes such as sinusitis, bronchopneumonia, reticuloperitonitis, pyelonephritis or mastitis (Stöber 2005). Bacterial dissemination from distant foci of infection occurs through the arterial circulation to the carotidal rete mirabile, while the spread from the soft tissues of the head as in rhinitis cases occurs through the venous circulation to the cavernous sinus (Fernandes \& Schild 2007, Câmara et al. 2009).

Brain abscesses are more common in adult cattle, sheep and horses. The most prevalent form reported are those caused by S. equi var. equi in horses (Mayhew 2009). Other bacteria, such as Enterococcus, Staphylococcus, Streptococcus, T. (Arcanobacterium) pyogenes, Fusobacterium necrophorum and Corynebacterium pseudotuberculosis may also be found primarily affecting ruminants (Barros et al. 2006, Fernandes \& Schild 2007). In goats, the reports of brain abscesses are scarce with the most prevalent microorganisms being T. (Arcanobacterium) pyogenes and C. pseudotuberculosis (Scott 2004, Mayhew 2009), and an unusual report of pyogranulomatous meningoencephalitis by $C$. ulcerans (Morris et al. 2005). The microscopic findings of Gram positive bacilli type bacteria strongly suggest that this case of leptomeningitis and thalamus abscess is secondary to parotideal caseous lymphadenitis. It is known that brain abscess manifest as a chronic process while suppurative leptomeningitis has an acute onset. So we believe that the abscess would be the primary cause of infection in the CNS. This finding suggests the possibility of caseous lymphadenitis have been the primary site of the pathology considering the hematogenous bacterial dissemination 
as described in the basilar empyema cases (Câmara et al. 2009). This fact was also evident in a case of pyogranulomatous meningoencephalitis after primary bacteremia due to otitis media (Morris et al. 2005).

In Northeastern Brazil, outbreaks of encephalitic listeriosis are linked to penetration of the mucosal barrier through injury or inflammation of the buccal or intestinal tract mucosa or to dental disease (Schild 2007). In addition, this outbreak presents the epidemiology similar to those in countries of North America and Europe; where listeriosis is often associated with ingestion of poorly fermented silage $(\mathrm{pH} \geq 5.5)$ that provides an excellent substrate for survival and possible multiplication of the microorganism; especially in low quality silages (Brugère-Picoux 2008). In this particular outbreak, the owner reported that the sheep flock was supplemented during the dry season with corn and sorghum silage stored in trench silos, with the presence of moldy areas. The first cases occurred approximately one month after the use of the silage corroborating previous data mentioning the incubation period of the encephalic form varying between four and six weeks (Ribeiro et al. 2006, Brugère-Picoux 2008). Pathological findings are similar to previous studies in others regions of Brazil (Ribeiro et al. 2006, Rissi et al. 2010). In this outbreak and the sporadic case, microbiological culture of CNS fragments or CSF presented as extremely helpful laboratory tool for the definitive diagnosis of listeriosis in sheep.

Suppurative meningitis is common in livestock during the neonatal period, and is associated with immunosuppression, which can be caused by inadequate colostrum intake, malnutrition, viral infection or other diseases causing immunosuppression (Marchen et al. 2005, Lemos \& Brum 2007). Gram-negative bacteria, E. coli in particular, are reported to be the most common meningeal pathogens in bovine neonates (Fecteau \& George 2004). In sheep and goats, E. coli, Pasteurella, Streptococcus, Staphylococcus pyogenes, and T. (Arcanobacterium) pyogenes have been cultured from meningitis cases (Marchen et al. 2005, Lemos \& Brum 2007). Some E. coli virulence factors may be of importance in the development of suppurative meningoencephalitis, because the successful meningeal pathogen would have overcome sequential host defenses mechanisms to reach the CSF and replicate. Before invading the meninges, the pathogen must colonize host mucosal epithelium. Bacterial omphalophlebitis or severe enteritis may lead to bacteremia without previous mucosal colonization. In calves, hematogenous bacteria survive because of inadequate colostral transfer (Fecteau \& George 2004, Mayhew 2009). In the E. coli meningoencephalitis outbreak, just CNS gross lesions were evident in the necropsy. This fact suggests that the low quality roughage might have caused damage to the oral mucosa and this was the primary site of bacterial colonization and dissemination. In the 21-day-kid and the Somalis lamb fed just with maternal milk, the fecal-oral route was suspected associated to dental eruption. Meanwhile, the Stenotrophomonas meningitis calf presented bacterial omphalophlebitis. The owner also stated that the dam was in poor body score, and possibly this fact triggered the production of poor quality or insufficient colostrum. In this particular case, two risk factors (inadequate colostral transfer and omphalophlebitis) might be involved in the pathogenesis of the disease.

It is noted that the greater importance of CSF analysis was to perform the differential diagnosis with other CNS diseases that cause similar neurological signs, among them infectious diseases caused by viruses such as rabies and bovine herpesvirus- 5 meningoencephalitis, or metabolic disturbances as lead poisoning and polioencephalomalacia (Barros et al. 2006, Câmara et al. 2009).

The diagnosis of these outbreaks was based on the association of epidemiological, clinical, pathological and bacteriological findings; reiterating that the infectious component remains an important cause of CNS disease in domestic ruminants and also shows the need for dissemination of information about the most effective preventive measures for the ranchers.

\section{REFERENCES}

Barros C.S.L., Driemeier D., Dutra I.S. \& Lemos R.A.A. 2006. Doenças do sistema nervoso de bovinos no Brasil. Vallée, Montes Claros. 207p.

Brugére-Picoux J. 2008. Ovine listeriosis. Small Rumin. Res. 76(1):1220.

Câmara A.C.L., Borges J.R.J., Godoy R.F., Moscardini A.R.C., Mustafa V.S., Castro M.B., Ximenes F.H.B., Paludo G.R., Perecmanis S. \& Drummond V.O. 2009. Síndrome do abscesso pituitário em bezerros na Região Centro-Oeste. Pesq. Vet. Bras. 29(11):925-930.

Dirksen G., Gründer H.-D. \& Stöber M. 1993. Rosenberger, Exame Clínico dos Bovinos. 3aㅡ ed. Guanabara Koogan, Rio de Janeiro. 419p.

Fecteau G. \& George L.W. 2004. Bacterial meningitis and encephalitis in ruminants. Vet. Clin. North Am. Food Anim. Pract. 20(2):363-377.

Fernandes C.G., Schild A.L., Riet-Correa F., Baialardi C.E.G. \& Stigger A.L. 2000. Pituitary abscess in young calves associated with the use of a controlled suckling device. J. Vet. Diagn. Invest. 12(1):70-71.

Fernandes C.G. \& Schild A.L. 2007. Abscessos do sistema nervoso, p.202207. In: Riet-Correa F., Schild A.L., Lemos R.A.A. \& Borges J.R.J. (Eds), Doenças de Ruminantes e Eqüídeos. Vol.1. Palotti, Santa Maria.

Jain N.C. 1993. Essentials of Veterinary Hematology. Lea and Febinger, Philadelphia. 417p.

Kramer J.W. 2000. Normal hematology of cattle, sheep and goats, p.1075-1084. In: Feldman B.F., Zinkl J.G. \& Jain N.C. (Eds), Schalm's Veterinary Hematology. $5^{\text {th }}$ ed. Lippincott Williams and Wilkins, Philadelphia.

Lemos R.A.A \& Brum K.B. 2007. Meningite bacteriana, p.381-383. In: Riet-Correa F., Schild A.L., Lemos R.A.A. \& Borges J.R.J. (Eds), Doenças de Ruminantes e Equídeos. Vol.1. Palotti, Santa Maria.

Loretti A.P., Ilha M.R.S., Riet-Correa G., Driemeier D., Colodel E.M. \& Barros C.S.L. 2003. Síndrome do abscesso pituitário em bezerros associada ao uso de tabuleta nasal para desmame interrompido. Pesq. Vet. Bras. 23(1):39-46.

MacFaddin J.F. 2000. Biochemical Tests for Identification of Medical Bacterial. Philadelphia: Lawrence McGrew, Lippincott Williams and Wilkins, Philadelphia. 901p.

Marchen M.R., Waldrigde B.M., Cebra C., Cebra M., Belknap E.B., Williamson L.S. \& Pugh D.G. 2005. Enfermidades do sistema neurológico, p.311-352. In: Pugh D.G. (Ed.), Clínica de Ovinos e Caprinos. Roca, São Paulo.

Mayhew I.G.J. 2009. Large Animal Neurology. $2^{\text {nd }}$ ed. Wiley-Blackwell, Iowa. 453p.

Morris W.E., Uzal F.A. \& Cipolla A.L. 2005. Pyogranulomatous meningoencephalitis in a goat due to Corynebacterium ulcerans. Vet. Rec. 156(10):317-8.

Ribeiro L.A.O., Rodrigues N.C., Fallavena L.C.B., Oliveira S.J. \& Brito M.A. 
2006. Listeriose em rebanho de ovinos leiteiros na região serrana do Rio Grande do Sul: relato de caso. Arq. Bras. Med. Vet. Zootec. 58(3):316319.

Rissi D.R., Kommers G.D., Marcolongo-Pereira C., Schild A.L. \& Barros C.S.L. 2010. Meningoencefalite por Listeria monocytogenes em ovinos. Pesq. Vet. Bras. 30(1):51-56.

Schild A.L. 2007. Listeriose, p.352-357. In: Riet-Correa F., Schild A.L., Lemos R.A.A. \& Borges J.R.J. (Eds), Doenças de Ruminantes e Equideos. Vol.2. Palotti, Santa Maria.

Stöber M. 2005. Enfermidades de los órganos del sistema nervioso central, p.933-1057. In: Dirksen G., Gründer H.D. \& Stöber M. (Eds), Me- dicina Interna y Cirugía del Bovino. Vol.2. 4⿳a ed. Intermédica, Buenos Aires.

Scott P.R. 2004. Diagnostic techniques and clinicopathologic findings in ruminant neurologic disease. Vet. Clin. North Am., Food. Anim. Pract. 20(2):215-230.

Scott P.R. 2010. Cerebrospinal fluid collection and analysis in suspected sheep neurological disease. Small Rumin. Res. 92(1/3):96-103.

Stokol T., Divers T.J., Arrigan J.W. \& McDonough S.P. 2009. Cerebrospinal fluid findings in cattle with central nervous system disorders: a retrospective study of 102 cases (1990-2008). Vet. Clin. Pathol. 38(1):103112. 